\title{
Implementation and Peculiarities of English for Specific Purposes Course Design at Ogarev's Mordovia State University
}

\author{
A. V. Lebedev ${ }^{1}$, I. S. Pinkovetskaia ${ }^{2, *}$, M. A. Rozhkov ${ }^{1}$, L. V. Tsybina ${ }^{1}$ \\ ${ }^{1}$ Department of Foreign Languages, N. P. Ogarev's Mordovia State University, Saransk, Russia \\ ${ }^{2}$ Department of State Administration, Ulyanovsk State University, Ulyanovsk, Russia
}

Received November 5, 2019; Revised November 26, 2019; Accepted December 4, 2019

Copyright $(2020$ by authors, all rights reserved. Authors agree that this article remains permanently open access under the terms of the Creative Commons Attribution License 4.0 International License

\begin{abstract}
The following article provides the description of implementing ESP (English for Specific Purposes) courses in both foreign and Russian higher educational institutions and deals with the experience of ESP teaching at Ogarev Mordovia State University (Saransk, Russia). The purpose of the study is to consider some practical challenges and tasks of teaching ESP on both international and Russian level and provide the possible solutions for them. Due to high relevance of the stated problem, the authors pay much attention to the review of literature, pointing out some of the most prominent scholars, who have studied theoretical and practical aspects of ESP teaching process and greatly contributed to the increase of scientific awareness in the field. The authors analyze the typical issues arising in the University teaching practice and point out such aspects as: the importance of proper selection of educational materials for the ESP training courses, the issue of homogeneous or so-called 'multilevel' academic groups, the necessity for thorough and due ESP course design and development etc. Several important conclusions are made: the authors point out the importance of thorough students' needs analysis prior to starting a course; the possible scenarios for significant adaptation of course contents due to constant changes in national educational standards and curricula hours; the highly responsible role of an ESP teacher, a professional, performing multiple assignments.
\end{abstract}

Keywords English for Specific Purposes, English for General Purposes, Professional-oriented Language Learning, Modern Teaching Issues

\section{Introduction}

Due to the growing trends of globalization, scientific cooperation and modernization of the Russian educational system, teaching ESP (English for Special Purposes) is becoming an increasingly important and challenging task for many professionals in this field. In accordance to provisions of modern educational standards, graduates of non-linguistic specialties are required to master all types of speech techniques, interpretation and translation, listening, lexical and grammar skills for successful professional and scientific activities.

The academic novelty of the given paper is conditioned by:

- the systematization of ESP teaching experience and methodology applied at the higher education institutions;

- the identification of the most relevant aspects of ESP teaching at Ogarev's Mordovia State University (educational resources, multi-level groups);

- the emphasis on the issue of ESP course design.

The study is aimed to consider the practical aspect of teaching ESP along with some of the most typical problems and challenges faced by teachers in the course of educational process in both foreign and Russian higher institutions. The research also deals with the determination of the specific tasks that teachers are currently facing, and it also considers several possible solutions.

The significance of this issue is connected with the fact that nowadays the level of students' linguistic competence studying at non-linguistic specialties and training fields does not always meet the necessary requirements. This phenomenon calls for certain restructuring of classes, changing the traditional methods of training (consistent study of lexical and grammar schemes, lexical units, translation of texts in any professional field) in favor of innovative methodological techniques aimed at the development of professionally-oriented communication skills while using the foreign language. This fact raises the 
challenge of rethinking the existing methods and techniques of ESP teaching.

\section{Literature Review}

Theoretical and practical aspects of ESP teaching are reflected in multiple works dealing with the problems faced by ESP practitioners. They are widely considered by researchers Dudley-Evans \& St John (1998), Hutchinson \& Waters (1987), Ferguson (1997), Hyland (2006), Hess (2001), Cenaj (2015). Several Russian scholars like Mitrofanova (1973), Polyakov (2003), Ter-Minasova (2000) dealing with the importance of communicative approach in ESP training need to be mentioned as well.

When discussing the conditions for successful implementation of occupational language courses, the founders of the modern job-oriented approach Hutchinson \& Waters (1987) point out the need for careful study of students' demands and requests. They state that the difference between English for special purposes and general English is not "the existence of a need as such but rather the awareness of that need". If all participants of the educational process are aware of the purposes students actually study English for, this knowledge will provide the significant impact on the selection of appropriate contents of the ESP course and ensure the successful disclosure of its potential. Scientists conclude that the content of the course (e.g. Science, Medicine, Business, Tourism) is secondary to its main characteristic - the ability to successfully determine the need to learn English for special purposes.

In this regard, it should be noted that starting a career as an ESP teacher, most university practitioners face difficulties in analyzing students' demands and requirements. The reason is that it is often difficult for students to predict their future needs, and they do not have a clear idea of what skills they may use in their future profession. Insufficient student motivation can also be a significant disorienting factor leading to further difficulties in the educational process.

Studying the problem of analysis of students ' needs, the researcher Cenaj (2015) notes that mistakes and inaccuracies may inhibit the successful achievement of the learning goals, and therefore the choice of appropriate teaching methods, methodology and contents of ESP course can lead to ineffective results. Accordingly, those inaccuracies can lead to the students' demotivation and consequently the course will not be able to satisfy their current and future needs.

Another difficulty often mentioned by the researchers in the field is ESP practitioners' insufficiency of subject methodology. Lack of knowledge leads to situations and problems which are increasingly complicated to deal with. Hutchinson \&Waters (1987) describe this condition of ESP teachers as "a new environment for which they are usually poorly prepared".

For example, teaching business English can prove to be a difficult task for specialists who previously worked only in the linguistic department, requiring them to expand their knowledge in this professional field over a rather short time frame.

According to Ferguson (1997), the lack of substantive knowledge should not affect the motivation and self-esteem of the teacher. He states that the ESP teacher should primarily act as an "expert in the field of language, not in the subject area". Researchers also point out a disproportionately large number of roles required from ESP practitioners in the teaching process. One of the most known ESP theorists Dudley-Evans \& St John (1998) introduces the term "ESP practitioner" (a specialist combining five roles):1) teacher, 2) employee, 3) course and educational materials developer, 4) researcher, 5) specialist evaluating acquired knowledge. The ESP teacher not only directly conducts a foreign language course for special purposes, he or she is involved in the development of course design, selection and adaptation of methodological content, is engaged in the design of educational materials, evaluation of the acquired knowledge, cooperation with teachers leading the subject courses. Under these circumstances, the task of any ESP practitioner becomes extremely difficult.

\section{Teaching Issues}

International experience of ESP teaching and the training issues manifest the similarities in the pedagogical problems to the Russian realities. However, we can point out the existence of certain aspects depending on the peculiarities of a national system of higher education and certain characteristics of the educational process.

Experience and regular practice of teaching English for Specific Purposes of the experts of Ogarev's Mordovia State University provide an opportunity to identify several of the most pressing problems that currently exist in the area of teaching ESP.

\subsection{Educational Resources}

One of the most difficult tasks in ESP teaching is the process of selecting methodological materials for the course. According to researcher Hyland (2006), educational content plays a key role in ESP, and its selection depends on the accepted methodology forming "an interface between teaching and learning, or certain contact points, in which the goals and objectives of the course become tangible for both students and teachers". The scholar stresses that educational materials are used to stimulate the teaching process, and their design and/or adaptation are an important element of ESP practice. Despite the prevalence of printed methodological 
resources, they may also include audiovisual materials, computer and internet simulators, actual objects and realities / case studies of professional activity area.

Thus, by listing the current issues related to the selection of suitable ESP training materials, one should consider the following important steps during this process:

- ESP teacher should take into account the length of the course and its possible adaptation to the actual number of curriculum hours;

- Careful analysis of the course target audience (students' needs and goals) is required;

- Structural organization of the course should correspond to its objectives: students need to have an idea of the education ultimate goal; teaching is to set the aim of step-by-step mastering the competences stated in the curriculum;

- Course glossary should be useful, authentic and frequently used by professionals in the field;

- Appropriate use of idiomatic English is crucial;

- Course materials should be 'live', visual and motivational for students to expand their knowledge in the chosen field;

- The use of the Internet in the implementation of the ESP course gives a golden opportunity to model situations of professional communication.

The discussion of the specific solutions related to the issue can be found in the last section of this article.

\subsection{Multilevel Groups}

The problem of multilevel groups has been studied by many scholars (Dudley-Evans\& St. John, 1998; Hess, 2001). Researchers note that this problem is one of the most relevant in the implementation of the ESP course. Students differ by their initial level of language competence, learning style, language abilities, age, motivation level, self-discipline (Halpern, 2013).

This problem is one of the most common among ESP teachers at Mordovia State University, as it is much more difficult to select the relevant educational materials for the course. Most teachers point out the low level of student language skills especially in the first year of study. One possible solution is to identify the individual needs of each student, create appropriate mini groups within each individual academic group and provide individual students or mini groups with materials or projects pertinent to their level of language training. The involvement and interest of each student in the educational process should be ensured, much attention is to be paid to the advanced students.

At present, the so-called "entrance test" for checking the foreign language skills is carried out at Mordovia State University. It precedes the process of formation of academic groups in almost all academic departments. As a result, the formation of groups takes into account the level of students' language training. However, in some fields of training and specialties this test is not possible due to the insufficient number of students. For example, the number of students at Jurisprudence specialty is sufficient for this test, whilst conducting it with the students of Design is not feasible.

In addition to the "entrance" test some intermediate tests are regularly conducted to monitor students ' progress and adjust the pace of implementation to the relevant training modules.

It should also be stated that many modern teaching materials take into account the possibility of teaching ESP in a diverse group, which greatly facilitates the teacher's work and contributes to the successful achievement of learning goals.

\subsection{Course Development and Design}

The final issue we would like to address in this paper is the design of the ESP course and the related issues that may arise during this process.

According to Cherkashina (2015), the main reason for insufficient effectiveness of ESP teaching in a non-linguistic university is the lack of attention paid to students' psychophysiological peculiarities. The researcher notes the difference between the system of language and the system of exact sciences, which also results in differences in thinking and consciousness.

According to the researcher, teachers of the humanities need to take into account that ESP training involves a significant restructuring of cognitive systems in language proficiency. As the solution to this problem, the author proposes the use of a project model involving the characteristics of professional consciousness and thinking of students.

It should be noted that the teacher takes full responsibility for the developed course, he or she makes the final decision on lexical, grammar and communicative skills taught to students, he is the one to decide which modules and language sections should be included. However, it is obvious that students' successful language mastering of the course is not guaranteed. When developing ESP courses at Mordovia State University, teachers take into account several factors: the existing Federal Standard for Higher Education and its provisions, the possibility of doing master's degrees by some students, feedback from employers and university graduates, student needs and teacher enthusiasm. Skills usually emphasized by teachers include the ability to reproduce oral annotation of the text in the subject field, ability of the speaker to respond adequately in various situations of professional communication, creation of a project in the chosen field of professional activity, ability to participate in business correspondence. The course design must be created with each of the above considerations concerned.

Another effective form of ESP teaching applied at Mordovia State University is the round-table talks or debates on controversial issues in a given field. At the 
preparatory stage students are invited to mobilize their linguistic knowledge and skills, use critical thinking, develop non-lateral thinking (Lebedev \& Tsybina, 2018). During the debate sessions, students demonstrate not only language training, but also vocational skills and competences. At the Department of English for Professional Communication of Mordovia State University, there are regular debates on a wide range of professional topics: "Capital Punishment: For and Against", "Our Votes: Do They Really Matter?", "Can Financial Problems Destroy a Country?" etc.

\section{Implementation and Peculiarities of ESP Courses}

A significant difficulty in selecting and adapting materials for an ESP course in Mordovia State University is the issue of balance. Thus, what should the correlation be between the language and subject-oriented resources selected for the course and the sources of information? Purely linguistic materials effectively contribute to the development of foreign language communication skills, while the subject-oriented sources of information focus on students gaining the knowledge needed for future professional activities.

Organization of ESP courses by employees of Ogarev's Mordovia State University demonstrates that finding this balance is mainly individual for ESP teachers and depends on the level of language training and needs of each individual student group. In case of insufficient level of first year students' language training, this balance shifts towards pure language sources at the initial stage allowing to prepare students for work directly in the subject field in the future.

Speaking about the choice of printed materials for the ESP course, it can be stated that in general this process does not differ from the situation with the course of General English, i.e. teachers of Ogarev's Mordovia State University conduct the individual selection of language and specialized educational materials in the corresponding field take into account the peculiarities of all the speech activity aspects (reading, writing, listening, speaking skills). However, a number of methodological problems associated with the selection of training materials are to be mentioned here:

- Insufficient availability of the necessary quantity of specialized methodological materials for some training fields. For example, such a shortage is traditionally observed when working with Design and Media Communication training fields;

- $\quad$ Level of pre-university language training required to work successfully with some textbooks may not match the language skills of specific academic groups. In this case, the teacher faces the need to adapt the teaching material substantially;
- Number of classes provided by the textbook may not correspond to the duration of the ESP course. In this case, the language practitioner should determine the modules that are to be excluded from the course or added to it.

We should also note the importance of using the Internet during the ESP course, as Ogarev's Mordovia State University ESP teachers have permanent access to the Internet and implement it in the educational process. The Internet offers new promising opportunities that increase the benefits of modeling professional communicative situations for students. For example, it can be used as a tool to enable authentic communication in typical situations, provide a context that represents practical speech situations; it provides students with the access to a large number of discipline-related and relevant language resources.

It should be mentioned that Ogarev's Mordovia State University students and teachers currently have access to the electronic data and educational environment e.g. Russian (eLibrary, EBS Lan, ZNANIUM.COM, etc.) and foreign (Freedom collection, eBook collection, Springer link etc.) library and information systems. This opportunity greatly facilitates the selection of necessary training materials for almost all areas of training and specialties.

\section{Conclusions}

As noted above, analysis of students' needs plays a key role in ESP. Therefore, it is necessary to carry out a full observation of the students' needs prior to designing the course. Dudley-Evans \&St. John (1998) propose a comprehensive study of the environmental situation, personal information, language training of students and their weaknesses, their expectations from the course, professional information about students and their ability to communicate in the target situation.

In addition, due to several changes in educational standards and curricula currently taking place in higher education institutions, all ESP practitioners must be prepared to adapt the content and the duration of their courses to the new requirements.

In conclusion, we would like to point out that quality teaching of English for Specific Purposes is vital in institutions of higher education due to the great demand for professionals in the relevant fields. In the process of ESP training, teachers need to pay special attention to the correspondence of materials to the subject area of knowledge. On the basis of students needs' analysis, teachers need to highlight the skills that will be most demanded in the labour market. As noted by Lebedev \& Tsybina (2018), "according to the requirements of the new educational standards, students of non-linguistic departments are to master oral and written translation, all kinds of speech activity, listening, lexical and grammatical skills for academic and professional activities. 
Consequently, foreign languages' proficiency is one of the components of individual professional development". This leads to some problems in ESP teaching. We have considered the importance and complexity of selecting the training materials used in the course, challenges of multilevel groups and the importance of well-designed ESP course providing some possible solutions. In addition, one should also note the vital role of the ESP teacher, who also acts as a researcher, teaching methods' developer and organizer of the educational process.

\section{REFERENCES}

[1] Cenaj M. (2015). Pedagogical challenges of ESP teachers in Albania. Academic Journal of Interdisciplinary Studies, 4, pp. 489-493.

[2] Cherkashina E.I. (2015). Designing models of linguistic and educational process at a non-linguistic university. Pedagogical Review, 1(7), pp. 43-50

[3] Dudley-Evans T., St John M. J. (1998). Developments in English for Specific Purposes. Cambridge: Cambridge University Press, 301 p.

[4] Ferguson G. (1997). The teacher education and LSP. The role of specialized knowledge. Teacher Education for LSP / ed. by R. Howard, G. Brown. Clevedon: Multilingual Matters, pp. 80-89.

[5] Halpern D. F. (2013). Thought and Knowledge: An Introduction to Critical Thinking. New York: Psychology Press. 480 p.

[6] Hess N. (2001). Teaching Large Multilevel Classes. New York: Cambridge University Press, 196 p.

[7] Hutchinson T., Waters A. (1987). English for Specific Purposes: A Learning Centered Approach. Cambridge: Cambridge University Press, 183 p.

[8] Hyland K. (2006). English for Academic Purposes. An Advanced Resource Book. New York: Routledge, 359 p.

[9] Lebedev A.V., Tsybina L.V. (2018). Teaching English for Specific Purposes in the Russian Higher Education Institution: Issues and Perspectives. Modern Journal of Language Teaching Methods, 8 (12), pp. $103-108$.

[10] Mitrofanova O.D. (1973). Language of science and technical literature. Moscow: Moscow State University, 149 p.

[11] Polyakov O.G. (2003). English for specific purposes: theory and practice. Moscow: Tezaurus, $186 \mathrm{p}$.

[12] Ter-Minasova S.G. (2000). Language and intercultural communication. Moscow: Slovo, $624 \mathrm{p}$. 